\title{
The Now of History: Tomographic and Ficto- Critical Approaches to Writing About Sonic Art
}

\author{
Gail Priest \\ University of Technology Sydney (PhD Candidate) \\ 38 Cascade St, Katoomba, NSW Australia 2780 \\ gail.s.priest@student.uts.edu.au
}

\begin{abstract}
Sonic art concerns itself with the experience of listening, a sense perception markedly different to the visual. However the majority of commentary on sonic art utilises historical and taxonomical approaches dependent on theoretical structures that are inherently retinal. Expanding on Salomé Voegelin's proposal for a writing that stems from a 'sonic sensibility' $(2010,2014)$ this paper proposes a tomographic (as opposed to a topographic) approach, one that is generated from the embedded and embodied nature of the sonic experience. It is proposed that this tomographic subjectivity forms part of a ficto-critical writing methodology, in which creative and critical modes are intermingled. Ficto-criticism allows for an interplay of percept and concept that is proposed as a suitable match for sonic art in which these similar tensions play out. A number of texts by writers identified as using tomographic and ficto-critical strategies will be used to illustrate this approach including Daniela Cascella, Kodwo Eshun and Joanna Demers. This paper reflects the first stage of doctoral research that will continue, by analysis and enaction, to develop a legitimate place for fictocritical writing as a rigorous contribution to cultural commentary about sonic art.
\end{abstract}

Sonic art, sound art, sonic art theory, ficto-criticism, fictocriticism, sonic fiction, creative commentary

\section{INTRODUCTION}

How to write about sound so

when now is then there is a sense of present in this past.

Sonic art is a relatively recent area of practice emerging from both visual art and music fields and much of the critical discourse about it has developed from art theory with a much smaller contribution from musicology as it struggles to come to terms with the form when it manifests beyond the concert hall. This discourse often involves a topographic approach concerned with historical analysis and taxonomical mapping relying, arguably, on an inherently visual understanding of subject-object relations. However there is current discussion as to the inadequacy of visually oriented theory as a tool for discourse about the sonic realm (Voegelin 2010, 2014, 2016, 2019; Kapchan 2017; Lavender 2017; Steintrager \& Chow 2019). In light of these arguments this paper proposes a practical methodology that may facilitate a meeting between theory and the specificities of listening to sonic art.

At the core of this proposition is the notion of a tomographic approach to writing about sonic art, that within this paper is defined as artistic activities that are primarily focused on encouraging a deeper relationship with listening. Tomography, a term borrowed from the medical sciences, allows us to see the interior of a solid structure through the process of multiple cross-sectional slices. This notion is applied to writing about sonic art in the form of privileging an embedded, embodied yet outward seeking perspective: a perspective compatible with that of a listener but also a creator. This tomographic subjectivity forms a key part of an overall ficto-critical methodology. Ficto-criticism'1 refers to writing that combines fictional (including the poetic and personal) with theoretical and critical approaches, a writing that allows both the percept and the concept to exist in interesting tension to each other (Muecke 2002 p. 109). It is proposed that this is a promising methodology with which to engage the perceptual and conceptual tensions that occupy a large part of discourse about sonic art (Kim-Cohen 2009).

To illustrate my proposal, I will suggest a number of what I have termed extra-textual writings that I believe employ tomographic and/or ficto-critical strategies (knowingly or not) by Daniella Cascella, Kodwo Eshun and Joanna Demers. It is proposed that a tomographic, ficto-critical writing will allow future readers a better sense of the presentness of 
sound now passed, offering a rigorous and enriching addition to traditional, topographic sound writing.

\section{THE CALL TO EARS}

This paper proposes a response to the provocation from Voegelin that 'Critical discourse does badly in dealing with sound as it assumes and insists on the gap between that which it describes and its description (Voegelin 2010 p. xiv). This gap is the distance that is assumed to be required for the notion of objectivity within traditional modes of theorising.

There is currently significant discussion as to whether theory, as it has predominantly been utilised to date, has a retinal bias (Lavender 2017). While not utterly definitive it is interesting to consider that etymologically the word theory stems from the Latin word theōría meaning viewing (Kapchan 2017), an action which arguably requires a separation of subject and object, a critical distance. There are a number of sound writers who are attempting to find different ways of 'theorising' to reflect a less visually defined subject-object paradigm (Steintrager \& Chow; Voegelin 2010, Kapchan 2017). James Lavender suggests that there is a 'fundamental mismatch between the nature of sound qua object and the conditions of possibility for knowledge that are rooted in the intellectual traditions of the West' (2017 p. 245). Due to the 'theoretically indiscernible' object of sound theory, he says it subsequently becomes a meta- theory, 'a discipline in which the status of theory itself is at stake' (p. 246).

It is beyond the scope of this paper to pursue the ontology of sound-as-object in detail, rather this paper focuses more pragmatically on the proposal that within critical commentary on sonic art, the visually influenced subject-object relation manifests most clearly in the preoccupation with historical and philosophical mapping and the related critical interpretations and definitional statements. It is proposed (with more detail in section 3 ) that this topographic approach is reliant on maintaining a critical distance between subject and object which limits the ability to convey the experience of the creative act itself.

A clear example of mapping that is unapologetically aligned with a visual arts paradigm is Seth KimCohen's text, In the Blink of an Ear (2009). He aligns sonic art more within the history of conceptual gallery-based (visual) arts, demanding a de- emphasis on sonic art's sensorial and perceptual qualities. Cohen works through historical visual arts criticism by Greenberg, Fried and Krauss to redraw the territory along these conceptual lines.
Kim-Cohen's thesis is perhaps an extreme example (though not without interesting provocations), however within the body of arts-focused sound theory to date, a significant number of texts have been dedicated to historical and philosophical mappings: Kahn's Noise, Water Meat (2001), Licht's Sound A rt (2007), LaBelle's Background Noise (2010) and the anthologies by editors Cox and Warner (2006) and Sterne (2012). The value of this surveying and defining is uncontested, serving to establish and advocate for the field of sonic art. However now that the territory has been established, it is proposed that exploring alternate approaches to sonic art commentary, approaches that attend less to critical distance and territorial and philosophical defence and instead attempt to grapple with the sense-specificities and objectdefying qualities of sound and its manipulation within sonic art, may offer a valuable expansion of the commentary about the field.

\subsection{Sonic sensibilities}

Voegelin suggests that this expansion requires that we develop and write from a 'sonic sensibility' (2010, p xiii). The act of listening, by its nature, is one of immersion. We cannot be separate from a sound that we are hearing. Voegelin suggests that when we hear sound, we are in sound, and sound is in us (Voegelin 2010, p. 5). In this way we exist in a relationship with sound. This relationship is illustrated by Pierre Schaeffer's objets sonores which requires its correlate 'reduced listening' to come into effect (Schaeffer 2017, p. 212). It is in the intention to listen to the sound-in-itself, that the sound- in-itself can be manifested (Chion 2009, p. 31).

Attending to the relational nature of listening ensures that a listening subjectivity does not become solipsistic. Theories of embodied and enacted cognition reiterate the internal, external dynamics of the perceptual relationship. Our concepts are made through our bodies' engagement with world. Cognition is not simply a process of the brain/mind but one that is distributed through the body via the sensory-motor system which engages with the environment, that in turn engages with it (Gibson 1986; Varela et al. 1991; Noë 2009). Barsalou's theory of 'perceptual symbol systems' (1999) suggests that the sense modality with which we engage has significant influence on the concept that is developed. Thus our conceptual writing about sound should be deeply informed by the perceptual qualities inherent in listening.

Also significant to Voegelin's sonic sensibility is that the sonic relationship is temporal, elusive and 'doubtful'. She proposes that we can never know the 'truth' of the sonic object/phenomenon 'but can only invent it, producing a knowing for me' (2010, p. 5). This renders listening a generative and highly 
subjective experience that requires an equally generative and subjective narration. To do this I propose the notion of a tomographic subjectivity.

\section{TOWARDS A TOMOGRAPHIC, FICTO- CRITICAL WRITING}

\subsection{Tomography: out from within}

Tomography (from the Greek 'to write slices'), is the process whereby something of volume can be imaged by taking slices or sections via a penetrating wave. For example in a CT (Computer Tomography) scan, multiple $\mathrm{X}$-rays from different angles are combined to create a cross-sectional image so that the interior of a solid can be seen (Tomography, Wikipedia). I propose this in contrast to topography that is concerned with the study of surfaces such as those of land masses, an approach closely aligned with mapping.

While Voegelin does not use the term tomography as such, the notion of slices is prevalent, particularly in her discussion of sonic geographies (2014). As part of this she explores Michel de Certeau's analogy of viewing the city from the top of the World Trade Centre. He contrasts the godlike, panoptic perspective, in which a city can be read and mapped, to the experience of the 'Wandersmänner' below, those who walk the streets writing the text of a city without having a perspective to read it (de Certeau 1984, cited in Voegelin 2014, p. 23).

From this I would like to highlight de Certeau's proposition that surveying the Wandersmänner from above provides a map but misses 'what was: the act itself of passing by' (de Certeau 1984, p. 97). This mapping, he says, results in a forgetting, with the 'trace left behind...substituted for the practice' (ibid.). A tomographic approach, recompiled from multiple slices from within, offers an alternate way of discussing a sonic act, one that attempts to combat the flattening and erasure of the act in itself that can happen through mapping from a distance.

\subsection{The object of two subjects}

Choice of perspective (in another sense) also plays into Pierre Schaeffer's analysis of the object subject- relations in music. He proposes the object of sound exists between two subjects: Subject 1, the composer; and Subject 2, the receiver or listener (2012 p. 157). I propose that the different ways of approaching sound commentary preference different weightings within this triad. An historical, taxonomical approach preferences the Subject 1 and object relationship in which the composer's motivations, background and relations to the historical milieu are the focus. A materialist approach places emphasis on the properties of the object, measuring and analysing its physical properties, or indeed could concentrate on the notation or score. A phenomenological, perceptualist approach, is concerned with the effect of the object as experienced by Subject 2 .

Just as in the first relationship, where the object can be overwhelmed by excessive emphasis on the aura of the composer, the latter scenario presents the danger that the object can easily be deemphasised leaving only the experiences of Subject 2. This has given the perceptualist approach a poor reputation criticised by Connor as a kind of 'acousmania' (2015). As eluded to previously, Kim-Cohen also takes issue with a perceptualist approach as he suggests it ignores vital conceptual concerns (2009). To ensure a balance of subject-object- subject it is proposed that a tomographic subjectivity is deployed as part of set of ficto-critical strategies.

\subsection{Ficto-criticism: Concept \pm Percept}

Ficto-critical writing combines critical, theoretical and creative writing. It is a term that curiously has its major discourse within Australian academia in 1990s and 2000s, influenced by post-structuralist, postmodernist and feminist agendas (Muecke 1991, 1997, 2002; Brewster 1995; Kerr 1995; Kerr \& Nettelbeck 1998; Haas 2017). Gibbs defines writing as ficto-critical when it uses 'fictional and poetic strategies to stage theoretical questions and reads theoretical texts in any discipline in the light of their rhetorical strategies and figures' (2003, p. 309).

The key feature of ficto-critical writing is that it employs a complex approach to subjectivity in which Nettelbeck says the " distance" of the theorist/critic collides with the "interiority" of the author' in a way that identity 'declare[s] itself as a politic to be viewed, reviewed, contested, and above all engaged with' (1998, p. 12). This transparent, reflexive subjectivity offers an ethical dimension that makes explicit that it does not speak for the 'other' or offer a universal objective experience, mindful of the tensions at play in subject-object relations.

In addition to this complex subjectivity a range of other strategies may be present. These techniques include intertextuality over and above citation, as recontextualisation or re-reading; fragmentation; ambiguity, doubt and open-endedness with different perspectives allowed to resonate, unresolved, with each other; and formal, stylistic and meta play in which content and form are inextricably entwined (Kerr 1995; Gibbs 2005; Brewster 2005; Prosser 2009; Haas 2017).

Stephen Muecke (using a notion by Deleuze) proposes that the ficto or fictional/creative strategies activate the 'percept' while the critical 
elements express the 'concept' (Muecke 2002 p. 109). The negotiation of the concept-percept tensions within a text creates 'a space between' (Kerr \& Nettelbeck 1998), one that encourages a greater reflexivity in the reading and writing experience (Haas 2017). Brewster proposes that this interplay "enacts the process of thought, of learning, of writing and reading, and the "digestion" (or non-digestion) of knowledge' (1995, p. 90). As predominant tensions in sound theory revolve around the perceptual (e.g. Voegelin 2010, 2014), the conceptual (e.g. Kim- Cohen 2009, Connor 2012) and material (e.g. O'Callaghan 2009, Cox 2018), adopting a ficto- critical methodology suggests a fertile alternative to presenting artfocused sound theory.

\section{EXTRA-TEXTUAL SOUND WRITING}

There are already a number of writers creating sonic art-focused texts that sit between critical and creative worlds. For example Daniela Cascella's F M.R.L.: Footnotes, Mirages, Refrains and Leftovers of Writing Sound (2015), is a highly intertextual, fragmentary meta-text that takes as its subject matter the attempt to write about sound. She admits that this attempt is always failing suggesting that 'writing sound' amounts to a thanatography-a written account of a death ( $p$. 43). To combat the inherent failure she enters a parallel ekphrastic process (whereby one artwork attempts to capture the spirit of another artwork). What is born out of the struggle is a language that approaches 'the edge' (p. 27), where words fall 'out of their borders' and expire, just like sound (p. 23). For example:

\begin{abstract}
At Café Oto tonight Akio Suzuki hammers nails into a wood plank, in a resolute honing of sounds, a devoted action of closeness. For every nail in the wood, a pierce in the ears and a sharpened insight, inhear [sic]. The inner sides of Suzuki's hammering thump are darker than their outer part and softer at the edges than the centre. Hammering in this room, softer at the edges than the centre. (Cascella 2015 pp. 50-51)
\end{abstract}

With a more traditional approach we may be told a of Suzuki's conceptual preoccupations, biography, where his work is located within the ecosystem of international sound art, however Cascella chooses to report directly, in the present tense, from within the experience of the work. Not only does she convey the quality of the sound, but what it might be to be this sound. The notion of interiority and exteriority is explicated in terms of the sound, the space and the experience, something which her neologism 'inhear' attempts to capture. The conceptual underpinnings, the artist's oeuvre, where his work is coming from, are transmitted through the ruminations on the sensing of the work. We are shown rather than told. As an isolated fragment, this exemplifies how the presentness of the experience of a sonic act may be conveyed. The book is an accumulation of such fragments that are set into oscillation with and against each other, the negotiation of which requires a reflexive reading state, a creative mode of reading-listening in which the auditory imagination is foregrounded.

An illustration of words that fall out their borders can also be found in Kodwo Eshun's More Brilliant than the Sun: Adventures in Sonic Fiction (1999). Writing of 'the beat' within Afro-futurist music Jazz, Hip Hop and a host of other late 20th Century electronic genres - Eshun's supersaturated, hyper-detailed, psychedelic writing makes no attempt to hypothesise about the whole, rather it explicates and enacts the motion and motivation of the music.

\begin{abstract}
In Paranormal, rhythm is a heatseeking break which goes awol, reorganising sound into an aerodynamic epic. Each break branches, the rattlesnake break in the right speaker travels around your head, fading behind your neck, swallowing its tail. The left-side break fades away behind your head, interacting with the right in a subsonic turbulence, reemerging so close it grazes your head... (Eshun 1999, p. 69)
\end{abstract}

Eshun's prose itself focuses on rhythm, the repetition of the word break, punctuating the meter. The snake metaphor merges with the flight metaphor to conjure a mythic flowing creature that entangles. As a reader we are immersed in the centre of this sound, buffeted, enthralled and assaulted by it. While I don't know this track, I get a keen sense of what it is to listen to it. As with Cascella, it is in the accumulation and crossconnection of fragments that allow more overarching connections and significations to emerge. An historical or taxonomical analysis can tell where this music fits, what it might mean, but Eshun offers a tangible sense of what this music is, why it is and what it does for a listener.

Eshun subtitles his work 'sonic fiction', and Eleni Ikoniadou has suggested that sonic fiction offers a fertile approach to writing about sound (2017). She suggests: 'More than examining, archiving, or glorifying the history and theory of sound, sonic fiction works at the continual intersection of speculative theory, science fiction, and science fact' (2017, p. 255). Ikoniadou's agenda is totally sympathetic to that proposed here however with its focus on speculation, science fictionality and posthumanism, it is suggested that sonic fiction is a particular form or strand of ficto-criticism.

Also working within a speculative mode is Joanna Demers' Drone and Apocalypse: An Exhibit Catalog for the End of the World (2015). Demers uses a future-dated scenario to explore particular theoretical aims firmly rooted in the current-day. 
Framed as a catalogue for an exhibition taking place in 2213 , the book comprises the writings of Cynthia Wey, a fictional 21st Century artist and philosopher whose preoccupations are drone music and a pending apocalypse. Interspersing the essayistic material are proposals for artworks, which operate at two speculative levels: the work as it is conceptualised by the artist Wey; and the work as it is described as manifested by the fictional curators of the exhibition. An example of one of these works asks us to 'Imagine the loudest sound that has ever occurred. A sound one thousand times louder than that of the Krakatoa explosion.' (Demers 2015, p. 38). This text provocation is said to be accompanied by the quiet drone minimalism of Kyle Bobby Dunn's 'Butel'. Here we are asked to imagine two opposing sounds and the very consciousness of listening emerges from the fall out and failure of such an endeavour. The nesting of fictions within fictions allows Demers an expanded field for theoretical thought. The meta-theoretical framework opens up her analysis, both to her own speculation and ours, actively engaging us in a reflexive interrogation of the soundings that she is theorising.

While a true sense of ficto-criticality is more easily understood by considering the interplay of elements within a text as whole, this brief analysis of excerpts is intended to illustrate some approaches to discussing sonic acts. These approaches preference a sense of the experience of the work itself and use this as a vehicle to explore the conceptual notions at play.

\section{CONCLUSION}

The irony is not lost that this paper takes the form of traditional academic arguments and justifications rather than as an exemplification of ficto-critical writing, however the notions proposed form part of my doctoral project that, in its final form, will comprise equal parts theoretical and ficto-critical writing. In interplay with the thesis will be texts testing different ficto-critical strategies (including structural, citational, autobiographic, fictional and poetic experimentations) with evaluation of their effectiveness at articulating a sonic sensibility and balancing the notions of concept and percept. This body of writing will be designed for digital delivery (iBook, interactive pdf, web) exploiting the hypertextual, multimedia and interactive potentials of digital publication.

While this proposition could be seen as one of style, I offer Susan Sontag's defence that style and content are inextricably entwined and that 'every style embodies an epistemological decision, an interpretation of how and what we perceive' (2009, p. 35). My proposal to explore tomographic subjectivity and ficto-critical strategies to theorise sound acknowledges that sound writing that maps and defines the contentious field of sonic art has provided valuable definitional, philosophical and historical knowledges, but now there is the opportunity to further explore new ways of theorising sonic art. By exploring the experience of the sonic act in its present ephemerality, avoiding, as de Certeau suggests, the muting and erasing of an act through mapping, a tomographic subjectivity deployed within a ficto-critical methodology may offer ways in which the critical gap between subject and object may be collapsed or reconfigured. In this way, it is proposed, a future reader may get a more specific sense, a sonic sense, a present sense of an sonic act that has been committed to history. In this way the now of the past, can be brought forward to the future.

\section{REFERENCES}

Barsalou, L.W. (1999) Perceptual symbol systems. Behavioral and Brain Sciences, vol. 22, no. 04. Available from: http://www.journals.cambridge.org/abstract_S01 40525X99002149, accessed 11 August $20 \overline{1} 9$.

Brewster, A. (1995) Fictocriticism: Pedagogy and Practice. In: Guerin, C., Butress, P. \& Nettelbeck, A. (eds) Crossing Lines: Formations of Australian C ulture Proceedings, Adelaide 1995, Journal of the Association for the Study of Australian $\mathrm{Li}$ terature. Available from: https://openjournals.library.sydney.edu.au/index. php/JASAL/article/view/9958, accessed 9 September 2019. 89-92.

Cascella, D. (2015) F.M.R.L.: Footnotes, Mirages, Refrains and Leftovers of Writing Sound. (Ebook) Alresford Hants: Zero Books/John Hunt Publishing.

de Certeau, M. (1984) The $P$ ractice of E veryday Life. Berkeley: University of California Press.

Chion, M. (1983) Guide to S ound O bjects. P ierre Schaeffer and Mus ical Research. Trans. Dack, J. \& North, C. Paris: Éditions Buchet/Chastel. Available from: http://ears.pierrecouprie.fr/spip.php?article3597, accessed 10 July 2018.

Connor, S. (2015) Acousmania. Sound S tudies: Art, E xperience, Politics Conference, The University of C ambridge, 10t h J uly 2015. Available from http://stevenconnor.com/acousmania.html, accessed 12 November 2018.

Cox, C. (2018) Sonic F lux: Sound, Art and Metaphysics. (E-book) Chicago: University of Chicago Press. 
Cox, C. \& Warner, D. (eds) (2006) Audio Culture: Readings in Modern Music. New York, London: Continuum.

Demers, J. (2015) Drone an d Apocalypse: A $n$ Exhibit $C$ atalog $f$ or $t$ he $E$ nd of $t$ he $W$ orld. (Ebook) Winchester/Washington: Zero Books.

Eshun, K. (1999) More Brilliant $t$ han $t$ he Sun: Adventures in S onic F iction. London: Quartet Books.

Gibbs, A. (2003) Writing and the flesh of others. Australian F eminist Studies, vol. 18, no. 42. 309- 319 .

Gibson, J.J. (1986) The Ecological Approach to Visual Perception. New York/Hove: Psychology Press.

Haas, G. (2017) Ficto/critical Strategies, Subverting Textual Practices of Meaning, O ther, a nd SelfFormation (e-book). Bielefeld: transcript Verlag.

Ikoniadou, E. (2017) A Sonic Theory Unsuitable for Human Consumption. Parallax, vol. 23, no. 3. 252-265.

Kahn, D. (2001) Noise, Water, M eat. Cambridge Mass: The MIT Press.

Kapchan, D. (2017) Theorizing Sound Writing. (Ebook) Middleton CT: Wesleyan University Press.

Kerr, H. (1995) Fictocriticism, the 'Doubtful Category' and the 'Space Between'. In: Guerin, C., Butress, P. \& Nettelbeck, A. (eds) Crossing Lines: $F$ ormations of $A$ ustralian $C$ ulture Proceedings, Adelaide 1 995. Journal of $t$ he Association for the Study of Australian Literature. Available from: https://openjournals.library. sydney.edu.au/index.php/JASAL/article/view/995 8, accessed 9 September 2019. 93-96.

Kerr, H. \& Nettelbeck, A. (eds) (1998) the s pace between. Nedlands: University of Western Australia Press.

Kim-Cohen, S. (2009) In the $B$ link of $A \cap E$ ar: Toward a Non-Cochlear Sonic Art. (E-book) New York: Continuum.

LaBelle, B. (2010) Background Noise: Perspectives on Sound Art. New York, London: Continuum.

Lavender, J. (2017) Introduction: Sounding / Thinking. Parallax, vol. 23, no. 3. 245-251.

Licht, A. (2007) Sound Art: Beyond Music, Between Categories. New York: Rizzoli

Muecke, S. \& King, N. (1991) On Ficto-criticism. Australian Book Review, vol. 134. 13-14.

Muecke, S. (2002) The Fall: Fictocritical Writing. Parallax, vol. 8, no. 4. Available from: http://www.tandfonline.com/doi/abs/10.1080/135 3464022000028000, accessed 16 December 2018. 108-112.
Nettelbeck, A. (1998) Notes Towards an Introduction. In: Kerr, H. \& Nettelbeck, A. (eds). the $s$ pace bet ween. Nedlands: University of Western Australia Press. 1-17.

Noë, A. (2009) Out of O ur Heads: Why You A re Not Your Brain, and Other Lessons from the Biology of C onsciousness. New York: Hill and Wang.

O'Callaghan, C. (2009) Sounds and events. In Nudds, M. \& O'Callaghan, C. (eds). Sounds and Perception: New Philosophical Essays. (E-book) Oxford: OUP Oxford.

Schaeffer, P. (2012) In Search of a $C$ oncrete Music, trans. North, C. \& Dack, J. Berkeley: University of California Press.

Schaeffer, P. (2017) Treatise on Musical Objects: An Essay Across Disciplines, trans. North, C. \& Dack, J. Berkeley: University of California Press.

Sontag, S. (2009) Against Interpretation and Other Essays. (E-book) London: Penguin Modern Classics.

Steintrager, J.A. \& Chow, R. (eds) (2019) Sound Objects. (E-book) Durham/London: Duke University Press.

Sterne, J. (ed.) (2012) The Sound Studies Reader. London, New York: Routledge.

Tomography. https://en.wikipedia.org/wiki/Tomography, accessed 17 June 2018.

Varela, F.J., Thompson, E. \& Rosch, E. (1991) The Embodied Mind: Cognitive Science and $H$ uman Experience. Cambridge, Mass: MIT Press.

Voegelin, S. (2010) Listening to Noise and Silence: Towards a P hilosophy of Sound Art. New York: Continuum.

Voegelin, S. (2014) Sonic Possible Worlds: Hearing the Continuum of S ound. (E-book) New Yorkl London: Bloomsbury.

Voegelin, S. (2016) Sound Words and Sonic Fictions: Writing the Ephemeral. The Routledge Companion to Sounding Art. New York: Routledge. Available from: https://wwwtaylorfrancis-

com.ezproxy.lib.uts.edu.au/books/e/9781317672 777, accessed 24 April 2018. 10.

Voegelin, S. (2019) The $P$ olitical $P$ ossibility of Sound: $F$ ragments of $\mathrm{Li}$ stening. (E-book) London/New York: Bloomsbury.

\footnotetext{
${ }^{\mathrm{i}}$ The hyphenated form of the term is used as my research intends to emphasise the notion of the 'space between' that ficto-criticism generates, proposed by Kerr \& Nettelbeck (1998). The non-hyphenated form is used when quoting from others who chose alternate presentations.
} 